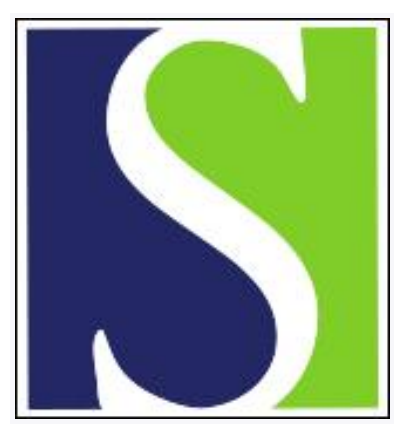

Scand J Work Environ Health 1998;24(2):118-124

https://doi.org/10.5271/sjweh.288

Issue date: Apr 1998

Occupational risk factors of lung cancer in São Paulo, Brazil

by Wünsch-Filho V, Moncau JE, Mirabelli D, Boffetta P

Key terms: case-referent study; epidemiology; job-exposure matrix; lung cancer

This article in PubMed: www.ncbi.nlm.nih.gov/pubmed/9630059

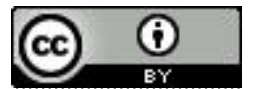




\title{
Occupational risk factors of lung cancer in São Paulo, Brazil
}

\author{
by Victor Wünsch-Filho, MD, ${ }^{1}$ José E Moncau, MPH, ${ }^{2}$ Dario Mirabelli, MD, ${ }^{3}$ Paolo Boffetta, MD ${ }^{4}$
}

\begin{abstract}
Wünsch-Filho V, Moncau JE, Mirabelli D, Boffetta P. Occupational risk factors of lung cancer in São Paulo, Brazil. Scand $J$ Work Environ Health 1998;24(2):118-124

Objectives This study estimated the risk of occupational exposure for lung cancer in the metropolitan region of São Paulo, the largest urbanized and industrialized area in Brazil.

Methods In this hospital-based case-referent study of 398 cases and 860 referents, the cases were matched to referents according to age, gender, and hospital and personally interviewed for information on lifetime job history, smoking habits, passive smoking exposure, cancer in relatives, socioeconomic status, and migratory history. The analysis concerned industrial titles and occupational categories. With the use of a job-exposure matrix, exposure to asbestos, polynuclear aromatic hydrocarbons, arsenic, dust, nickel and chromium was assessed.

Results For the men in the 56 industrial and 122 occupational categories examined, an excess risk of lung cancer was found in the machinery industry [odds ratio (OR) $1.62,95 \%$ confidence interval $(95 \% \mathrm{CI}) 1.02-$ 2.55). In pottery manufacturing the risk (OR $2.21,95 \%$ CI $1.00-4.87$ ) was increased for workers exposed $\geq 10$ years (OR $6.43,95 \%$ CI $1.12-37.01$ ). Textile workers employed for $\geq 10$ years with a latency of $\geq 40$ years had an elevated risk (OR 21.93,95\% CI 1.96-245.0). In the analysis using the job-exposure matrix no risk was detected for the specific lung cancer carcinogens examined. For the women, no significantly elevated risk was observed.

Conclusions The results of this study revealed risks of lung cancer for men in the machinery industry and for pottery and textile workers with long-term exposure.
\end{abstract}

Key words case-referent study, epidemiology, job-exposure matrix, lung cancer.

\begin{abstract}
After cardiovascular diseases, cancer is the second greatest cause of death among the Brazilian population above 40 years of age, and lung cancer represents the first neoplastic cause of death among men (1). The incidence of lung cancer is increasing in the country (2), and this growth has been associated with the increase in the prevalence of smoking (3). The incidence is higher in the southeast and southern states, the more urbanized and industrialized regions of the country $(4,5)$. In the city of São Paulo, data from the late 1970s showed an annual age-standardized lung cancer incidence rate of 36.5/100 000 for the male population (6). More recent figures are not available, but the incidence is likely to have increased.

Tobacco smoking is the major cause of lung cancer worldwide (7). Its role has been confirmed in the only study of lung cancer conducted so far in Brazil (8). In addition, several occupational factors have been shown to contribute

Faculdade de Saúde Pública. Universidade de São Paulo. São Paulo, Brazil.

Universidade Federal de São Paulo. São Paulo, Brazil.

Agenzia Regionale per la Protezione del Piemonte, Grugliasco, Italy.

International Agency for Research on Cancer, Lyon, France.
\end{abstract}

to the development of this cancer (9). The role of occupational factors on lung cancer varies greatly between countries and time periods (10). It is well documented that specific chemical substances and physical agents, including asbestos, polynuclear aromatic hydrocarbons (PAH), arsenic, dust, nickel and chromium, and occupations involving exposures to these agents increase the risk (11). In addition, several industrial branches involving complex chemical mixtures have been associated with an elevated risk of lung cancer (11).

The majority of studies on occupational factors for lung cancer have been carried out on workers from developed countries with old and well structured industrial processes, but the nature and magnitude of occupational lung cancer have been scarcely explored in developing countries (1214). Our objective was to try to explore this relationship in Brazil through a hospital-based case-referent study in the metropolitan region of São Paulo.

Reprint requests to: Victor Wünsch-Filho, Departmento de Epidemiologia, Faculdade de Saúde Pública, Universidade de São Paulo, Av Dr Arnaldo, 715, 01246—904, São Paulo, SP, Brazil. 


\section{Subjects and methods}

The metropolitan region in question is comprised of $37 \mathrm{mu}$ nicipalities and about 15.2 million people. It is the largest industrialized area in Brazil (15). The labor force includes about 7 million people, of whom $29.7 \%$ work in industry, $16.5 \%$ are employed in commerce, $43.8 \%$ do service work, and $10 \%$ are in other activities (16).

Data were collected in 14 hospitals from July 1990 to June 1991. The cases and referents were interviewed with the aid of a standard questionnaire with structured sections to obtain detailed information on tobacco smoking, passive smoking in childhood and adult life, cancer in the family, socioeconomic status, migration, medical history, and each job held for at least 6 months.

The cases available had been newly diagnosed as lung cancer, according to the International Classification of Diseases (ICD), ninth revision (17), from January 1989 to June 1991. The diagnosis was assessed from hospital records and only those confirmed by histology or cytology were accepted. Eligible cases with a definite diagnosis other than lung cancer were reclassified as referents if the diagnosis was among those retained for referents. Only residents living in the same metropolitan region as the cases for at least 6 months were included. Information was taken from $83.9 \%$ of the patients. For the subjects too ill to answer the questionnaire, proxy information was sought from next-of-kin: 9.3\% from a child, $4.5 \%$ from a spouse, and the rest from other relatives or people in close contact with the patient.

The cases and referents were matched for age ( \pm 3 years), gender, and hospital. For each eligible referent, the diagnosis abstracted from medical records was coded according to the ICD. Patients with chronic obstructive respiratory diseases and smoking-related cancers (bladder, larynx, esophagus, oral cavity, pharynx, pancreas, kidney and renal pelvis) were excluded. Altogether $89.9 \%$ of the referents were interviewed in person, while children, spouses and other next-of-kin contributed to $4.1 \%, 2.4 \%$ and $3.6 \%$ of the interviews, respectively.

Altogether 1258 persons were retained in the analysis: 398 cases and 860 referents. Selected characteristics of the cases and referents are shown in table 1 . The case-referent ratio was 1.7 for the men ( 307 cases and 546 referents) and 3.4 for the women ( 91 cases and 314 referents). For the male cases the average age was 62.5 years, and for the female cases it was 60.8 years. The corresponding values for the referents were 60.5 and 62.2 years. The job turnover during a lifetime was higher for the men (average of 4.4 jobs among the cases and 3.9 among the referents) than for the women (2.5 and 2.3, respectively).

The International Standard Industrial Classification of All Economic Activities (ISIC) (18) was used to classify industry and the International Standard Classification of Occupations (ISCO) (19) was used for occupations. The cases and referents were classified into 56 industrial and 122 occupa- tional categories. Only categories including at least 10 men employed (overall prevalence of exposure 1.17\%) or 6 women (overall prevalence of exposure $1.48 \%$ ) were included in the analysis. A 10 years' time lag of employment was considered to examine exposure duration, and 40 years since the first exposure was established as the cut point for latency. The calculations were made by summing the exposure periods from the first employment to the time of the lung cancer diagnosis.

A job-exposure matrix (JEM) was developed for assessing the specific lung carcinogens. Each subject's job history was used to set up a data base of all combinations of industrial activity and occupational titles ever held by any interviewee. An industrial hygienist and an occupational epidemiologist assessed, for every combination, the probability and intensity of exposure to asbestos, PAH, arsenic, dust, nick$\mathrm{el}$, and chromium. The assessment was scored blindly according to the following scale: no exposure (exposure similar to the general population's), definite low exposure (exposure higher than the general population's, but at levels experienced by some groups), possibly high exposure (job may add significant exposure, but information about job not completely available), definite high exposure (exposure definitely higher than that of the general population and information about job exposure reliable).

The analysis was conducted separately for the men and women. Odds ratios (OR) and $95 \%$ confidence intervals

Table 1. Selected characteristics of the cases and referents by gender.

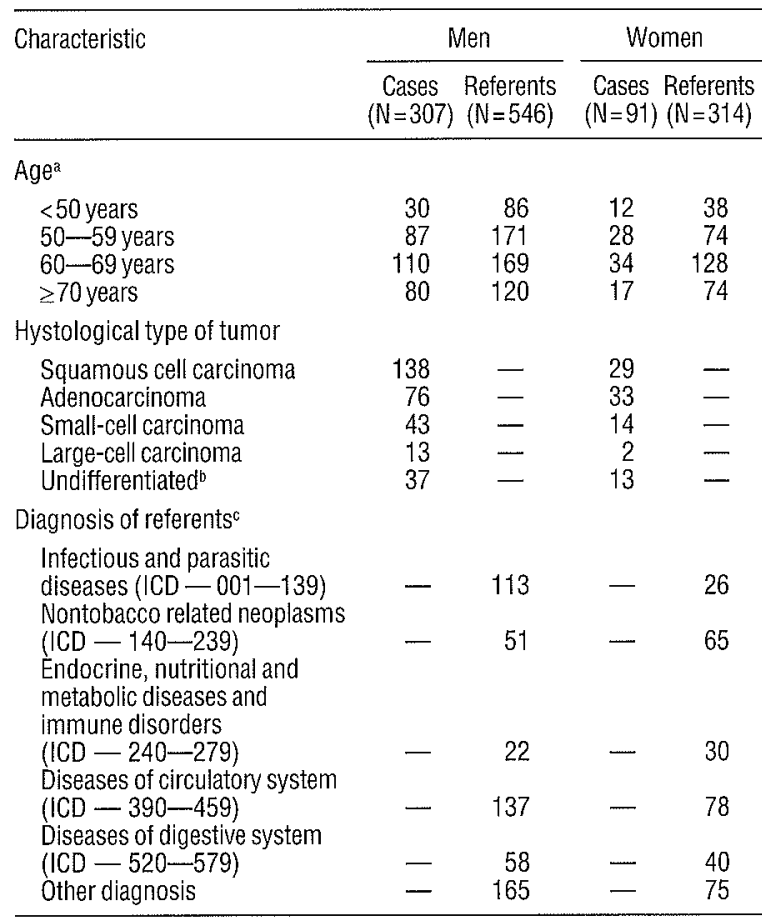

a Age range: $36-90$ cases; $33-90$ referents.

b It includes all tumors diagnosed by cytology.

c Code of the International Classification of Diseases in parentheses. 
$(95 \% \mathrm{CI})$ were calculated as approximations of relative risk (20). The risk of lung cancer was estimated by comparing subjects ever employed in a particular industrial or occupational category or ever exposed to an agent included in the job-exposure matrix with those never employed or exposed. Each subject could be counted as exposed in more than 1 industry or occupation and to more than 1 carcinogen. Potential confounders were controlled by unconditional logistic regression modeling (20). Statistical significance was assessed by the maximum likelihood ratio test (21).

\section{Results}

The proportion of squamous-cell lung cancer was higher for the men, and adenocarcinoma was predominant among the women. Only 34 (8.5\%) cases did not have the diagnosis established by histology. Cases confirmed by cytology were assumed to be of an undifferentiated type.

Almost three-fourths of the selected referents had a diagnosis included in the 5 main ICD code groups: diseases of the circulatory system (25.0\%), infectious and parasitic diseases (16.2\%), nontobacco-related neoplasms (13.5\%), diseases of the digestive system (11.4\%), and endocrine, nutritional and metabolic diseases and immune disorders (6.0\%). The remaining had diseases classified into other ICD groups, for example, bone fractures, rheumatoid arthritis, skin diseases, and complications of labor or delivery. The men had a higher proportion of infectious diseases $(20.7 \%$ ) and a lower proportion of neoplasms $(9.3 \%)$ than the women $(8.3 \%$ and $20.7 \%$, respectively).

Table 2 presents the risk of lung cancer from tobacco smoking. A step-gradient effect was observed for the men according to the number of pack-years.

Results for the men in 23 industries, when controlled for age, cigarette smoking, family history of cancer, migration, and socioeconomic status are shown in table 3 . Only machinery showed a significantly elevated risk of lung cancer. Two other industries (pottery and nonmetallic mineral manufacturing) showed (nonsignificant) risks higher than 1.5 . In the analysis for exposure duration ( $\geq 10$ years) and latency ( $\geq 40$ years) the risk increased in the pottery and nonmetallic mineral industry, but it did not change in the machinery industry. None of the 21 occupational categories examined showed a significantly increased risk of lung cancer (table 4).

With respect to histological type, the finance category revealed an increased risk of adenocarcinoma (OR 2.25, 95\% CI 1.15-2.66). Other industrial categories at increased risk of adenocarcinoma were wood, furniture, printing, chemicals and plastics, basic metal, machinery, and energy (all at $\mathrm{P}>0.05$ ).

We conducted an analysis for the men after excluding the cases and referents with information collected through proxy interviews. In general this approach increased, but not signif- icantly, the relative risks of the earlier analysis including proxy interviews. However for pottery and textile workers the risks increased: pottery workers: ever employed OR 2.54 $\& 95 \%$ CI $1.09-5.88$, employed $\geq 10$ years OR $13.78 \&$ $95 \%$ CI $1.49-127.43$, employed $\geq 10$ years and $\geq 40$ years of latency OR $14.13 \& 95 \%$ CI 1.54-129.97; textile workers: ever employed OR $1.00 \& 95 \%$ CI $0.43-2.34$, employed $\geq 10$ years OR $7.70 \& 95 \%$ CI $1.01-58.42$, employed $\geq 10$ years and $\geq 40$ years of latency OR $21.93 \& 95 \%$ CI $1.96-245.0$.

The results of the analysis using the job-exposure matrix for the male workers are shown in table 5. When the level and duration of exposure were taken into consideration, no increased risks were found for asbestos, $\mathrm{PAH}$, arsenic, dust, nickel, or chromium, but in the analysis with $\mathrm{a} \geq 40$-year latency the risks for these agents were somewhat high.

For the women, elevated risks of lung cancer, based on small numbers, were found for 2 industrial categories, leather (OR 2.93, 95\% Cl 0.74-11.56) and finance (OR 1.91, 95\% CI $0.63-13.40)$ and 2 occupational categories, laundresses (OR 2.88, 95\% CI 0.48-16.98) and hairdressers (OR 4.26, $95 \%$ CI $0.66-27.21)$. The analysis using the job-exposure matrix for the women was strongly hampered by the small number of exposed subjects.

\section{Discussion}

Out of 56 industrial and 122 occupational categories, only the categories of machine industry and pottery industry and textile worker occupation (excluding proxy interviews and including employment for $\geq 10$ years and latency for $\geq 40$ years) showed significantly elevated risks of lung cancer for the men. No significant risk was observed for the women.

Our study confirms tobacco smoking as an important risk factor of lung cancer for both men and women. This result is in the same direction as that of other studies from many countries (7), but the risk level is lower than those reported in Colombia (22). A possible explanation is our reference selection. One-quarter of our referents had a circulatory disease, and the proportion of smokers was probably higher in this group than in the general population and the effect therefore underestimated. When the referents with this ICD diagnosis were excluded, the effect of smoking increased for those smoking $\geq 61$ pack-years: men OR $9.34 \& 95 \% \mathrm{CI}$ 4.76 - 18.33; women OR $4.79 \& 95 \%$ CI $1.34-17.03$. The effect of controlling for cigarette smoking on the relative risks of the industrial and occupational categories and carcinogens assessed with the aid of the job-exposure matrix showed a trend towards elevated risks among the men (table 6).

When the occupational risks, the main objective of this study, were focused upon, the results for the pottery industry were particularly interesting. There was a borderline significant excess risk that increased for workers exposed for 
Table 2. Tobacco smoking and socioeconomic status and risk of lung cancer. (OR = odds ratio, $95 \% \mathrm{Cl}=95 \%$ confidence interval)

\begin{tabular}{|c|c|c|c|c|c|c|c|c|}
\hline & \multicolumn{4}{|c|}{ Men } & \multicolumn{4}{|c|}{ Women } \\
\hline & $\begin{array}{l}\text { Cases } \\
\text { (N) }\end{array}$ & $\begin{array}{l}\text { Referents } \\
\text { (N) }\end{array}$ & $\mathrm{OR}$ & $95 \% \mathrm{Cl}$ & $\begin{array}{l}\text { Cases } \\
\text { (N) }\end{array}$ & $\begin{array}{l}\text { Referents } \\
(\mathrm{N})\end{array}$ & $\mathrm{OR}$ & $95 \% \mathrm{Cl}$ \\
\hline \multicolumn{9}{|l|}{ Cigarette smokinga } \\
\hline $\begin{array}{l}\text { Never smokers } \\
\text { Ever smokers }\end{array}$ & $\begin{array}{r}14 \\
290\end{array}$ & $\begin{array}{r}99 \\
441\end{array}$ & $\begin{array}{l}1.00 \\
4.75\end{array}$ & $2.66-8.50$ & $\begin{array}{l}29 \\
60\end{array}$ & $\begin{array}{r}208 \\
98\end{array}$ & $\begin{array}{l}1.00 \\
4.43\end{array}$ & $2.62-7.47$ \\
\hline $\begin{array}{l}\text { Current smokers } \\
\text { Ex-smokersc }\end{array}$ & $\begin{array}{l}189 \\
100\end{array}$ & $\begin{array}{l}234 \\
200\end{array}$ & $\begin{array}{l}6.59 \\
3.28\end{array}$ & $\begin{array}{l}3.59-12.1 \\
1.77-6.07\end{array}$ & $\begin{array}{l}42 \\
17\end{array}$ & $\begin{array}{l}51 \\
36\end{array}$ & $\begin{array}{l}5.98 \\
3.51\end{array}$ & $\begin{array}{l}3.25-11.0 \\
1.74-7.10\end{array}$ \\
\hline \multicolumn{9}{|c|}{ Cigarette consumption in pack-years d,e } \\
\hline $\begin{array}{l}\leq 20 \\
21-40 \\
41-60 \\
\geq 60\end{array}$ & $\begin{array}{r}14 \\
68 \\
85 \\
105\end{array}$ & $\begin{array}{r}24 \\
120 \\
86 \\
94\end{array}$ & $\begin{array}{l}1.35 \\
4.20 \\
6.90 \\
7.74\end{array}$ & $\begin{array}{l}0.66-2.76 \\
2.18-8.09 \\
3.65-13.0 \\
4.12-14.6\end{array}$ & $\begin{array}{r}26 \\
14 \\
11 \\
5\end{array}$ & $\begin{array}{l}48 \\
12 \\
11 \\
10\end{array}$ & $\begin{array}{l}3.95 \\
8.98 \\
7.39 \\
3.60\end{array}$ & $\begin{array}{l}2.05-7.62 \\
3.58-22.5 \\
2.87-19.0 \\
1.14-11.4\end{array}$ \\
\hline \multicolumn{9}{|l|}{ Socioeconomic status ${ }^{\dagger, s}$} \\
\hline $\begin{array}{l}\text { Level } 1 \text { (lowest level) } \\
\text { Level } 2 \\
\text { Level } 3 \\
\text { Level } 4 \text { (highest level) }\end{array}$ & $\begin{array}{l}49 \\
96 \\
84 \\
34\end{array}$ & $\begin{array}{r}99 \\
160 \\
161 \\
45\end{array}$ & $\begin{array}{l}1.00 \\
1.05 \\
0.86 \\
1.34\end{array}$ & $\begin{array}{l}0.75-1.46 \\
0.62-1.21 \\
0.79-2.29\end{array}$ & $\begin{array}{l}24 \\
27 \\
18 \\
10\end{array}$ & $\begin{array}{l}68 \\
94 \\
80 \\
10\end{array}$ & $\begin{array}{l}1.00 \\
0.81 \\
0.76 \\
3.75\end{array}$ & $\begin{array}{l}0.45-1.46 \\
0.40-1.45 \\
1.36-10.3\end{array}$ \\
\hline
\end{tabular}

a 0 dds ratio adjusted by age; pure cigar and pipe smokers excluded from the analysis.

b Reference category.

- More than 1 year since cessation of smoking.

¿ Odds ratio adjusted by age.

- Reference category: never smokers.

+ Based on a combination of income per capita and level of education.

$\checkmark$ Odds ratio adjusted by age and smoking.

Table 3. Employment in selected industries and risk of lung cancer among the men. (OR = odds ratio, $95 \% \mathrm{Cl}=95 \%$ confidence interval)

\begin{tabular}{|c|c|c|c|c|c|c|c|c|c|c|c|c|}
\hline \multirow[t]{2}{*}{ Industry $\mathrm{a}_{\mathrm{a}} \mathrm{b}$} & \multicolumn{4}{|c|}{ Ever employed 6} & \multicolumn{4}{|c|}{ Employed $\geq 10$ years ${ }^{c}$} & \multicolumn{4}{|c|}{$\begin{array}{l}\text { Employed } \geq 10 \text { years and } \\
\geq 40 \text { years of latencyc }\end{array}$} \\
\hline & $\begin{array}{l}\text { Cases } \\
\text { (N) }\end{array}$ & $\begin{array}{l}\text { Refer- } \\
\text { ents } \\
\text { (N) }\end{array}$ & $\begin{array}{l}\text { Adjusted } \\
\mathrm{OR}^{\mathrm{d}}\end{array}$ & $95 \% \mathrm{Cl}$ & $\begin{array}{l}\text { Cases } \\
\text { (N) }\end{array}$ & $\begin{array}{l}\text { Refer- } \\
\text { ents } \\
\text { (N) }\end{array}$ & $\begin{array}{l}\text { Adjusted } \\
\mathrm{OR}^{\mathrm{d}}\end{array}$ & $95 \% \mathrm{Cl}$ & $\begin{array}{l}\text { Cases } \\
\text { (N) }\end{array}$ & $\begin{array}{l}\text { Refer- } \\
\text { ents } \\
\text { (N) }\end{array}$ & $\begin{array}{l}\text { Adjusted } \\
\mathrm{OR}^{\mathrm{d}}\end{array}$ & $95 \% \mathrm{Cl}$ \\
\hline Agriculture (1) & 104 & 236 & 0.72 & $0.50-1.04$ & 73 & 161 & 0.81 & $0.55-1.19$ & 66 & 139 & 0.81 & $0.54-1.21$ \\
\hline Food and tobacco (31) & 35 & 67 & 0.90 & $0.56-1.44$ & 9 & 19 & 0.72 & $0.31-1.70$ & 8 & 15 & 0.77 & $0.30-1.93$ \\
\hline Textile (321) & 20 & 42 & 0.98 & $0.54-1.79$ & 10 & 11 & 1.62 & $0.62-4.26$ & 9 & 9 & 1.67 & $0.60-4.68$ \\
\hline Leather (323) & 7 & 15 & 1.30 & $0.48-3.49$ & 2 & 3 & 1.12 & $0.17-7.60$ & 2 & 1 & 3.31 & $0.24-45.2$ \\
\hline Shoes (324) & 5 & 17 & 0.44 & $0.15-1.27$ & 1 & 4 & 0.35 & $0.03-3.65$ & 1 & 4 & 0.36 & $0.03-3.77$ \\
\hline Wood (331) & 18 & 23 & 1.41 & $0.71-2.81$ & 6 & 7 & 1.18 & $0.37-3.79$ & 6 & 6 & 1.34 & $0.40-4.51$ \\
\hline Furniture (332) & 11 & 14 & 1.44 & $0.59-3.49$ & 3 & 4 & 1.38 & $0.25-7.47$ & 3 & 3 & 1.68 & $0.28-10.2$ \\
\hline Printing (342) & 9 & 15 & 1.14 & $0.45-2.90$ & 3 & 5 & 0.86 & $0.18-4.20$ & 3 & 5 & 0.90 & $0.18-4.36$ \\
\hline $\begin{array}{l}\text { Chemicals and plastics } \\
\text { ( } 35 \text { excluding } 355 \text { ) }\end{array}$ & 26 & 40 & 1.22 & $0.70-2.14$ & 9 & 13 & 1.25 & $0.49-3.18$ & 9 & 10 & 1.44 & $0.54-3.81$ \\
\hline Pottery (361) & 16 & 15 & 2.21 & $1.00-4.87$ & 6 & 2 & 6.43 & $1.12-37.0$ & 6 & 2 & 6.51 & $1.14-37.2$ \\
\hline $\begin{array}{l}\text { Other nonmetallic mineral } \\
(362-369)\end{array}$ & 14 & 16 & 1.65 & $0.75-3.64$ & 4 & 2 & 5.32 & $0.88-32.1$ & 2 & 2 & 2.85 & $0.34-23.8$ \\
\hline Basic metal (37) & 34 & 54 & 1.34 & $0.82-2.20$ & 12 & 7 & 1.67 & $0.73-3.79$ & 7 & 9 & 2.02 & $0.67-6.11$ \\
\hline Metal products (381) & 38 & 60 & 1.28 & $0.79-2.05$ & 8 & 18 & 0.90 & $0.37-2.23$ & 6 & 14 & 0.78 & $0.28-2.16$ \\
\hline Machinery (382-384) & 48 & 60 & 1.62 & $1.02-2.55$ & 16 & 18 & 1.50 & $0.71-3.18$ & 14 & 13 & 1.73 & $0.74-4.04$ \\
\hline Other manufacturing (other 3 ) & 34 & 49 & 1.21 & $0.73-2.01$ & 16 & 19 & 1.35 & $0.64-2.84$ & 14 & 13 & 1.68 & $0.72-3.94$ \\
\hline Energy (4) & 11 & 14 & 1.27 & $0.54-3.02$ & 7 & 6 & 1.98 & $0.61-6.40$ & 7 & 6 & 1.96 & $0.61-6.33$ \\
\hline Construction (5) & 67 & 154 & 0.74 & $0.51-1.07$ & 46 & 91 & 0.91 & $0.60-1.40$ & 38 & 70 & 0.92 & $0.58-1.47$ \\
\hline Trade $(61-62)$ & 8 & 19 & 0.67 & $0.27-1.63$ & 5 & 10 & 0.76 & $0.24-2.40$ & 5 & 6 & 1.12 & $0.31-4.01$ \\
\hline Restaurants hotels (63) & 7 & 13 & 0.97 & $0.36-2.63$ & 2 & 2 & 2.57 & $0.30-21.8$ & 2 & 1 & 7.03 & $0.52-94.3$ \\
\hline Transport (7) & 57 & 106 & 0.98 & $0.66-1.46$ & 31 & 54 & 1.01 & $0.60-1.68$ & 26 & 41 & 0.97 & $0.55-1.71$ \\
\hline Finance business $(8)$ & 35 & 51 & 1.12 & $0.68-1.86$ & 14 & 27 & 0.77 & $0.37-1.56$ & 9 & 21 & 0.55 & $0.24-1.27$ \\
\hline Social services (91-94) & 73 & 149 & 0.82 & $0.57-1.17$ & 39 & 86 & 0.70 & $0.44-1.10$ & 28 & 70 & 0.58 & $0.35-0.97$ \\
\hline Personal services (95) & 14 & 22 & 1.29 & $0.62-2.70$ & 4 & 13 & 0.63 & $0.19-2.09$ & 4 & 12 & 0.76 & $0.23-2.55$ \\
\hline
\end{tabular}

a Categories with at least 10 subjects employed.

${ }^{b}$ Code of the International Standard Industrial Classification of All Economic Activities in parentheses.

- Reference category: never employed.

Odds ratio adjusted for age, cigarette smoking, cancer in family, migratory history, and socioeconomic status. 
Table 4. Employment in selected occupations and risk of lung cancer among the men. (OR $=$ odds ratio, $95 \% \mathrm{Cl}=95 \%$ confidence interval)

\begin{tabular}{|c|c|c|c|c|c|c|c|c|c|c|c|c|}
\hline \multirow[t]{2}{*}{ Occupation ${ }^{\mathrm{a}, \mathrm{b}}$} & \multicolumn{4}{|c|}{ Ever employedc } & \multicolumn{4}{|c|}{ Employed $\geq 10$ years ${ }^{c}$} & \multicolumn{4}{|c|}{$\begin{array}{l}\text { Employed } \geq 10 \text { years and } \\
\geq 40 \text { years of latencyc }\end{array}$} \\
\hline & $\begin{array}{c}\text { Cases } \\
(\mathrm{N})\end{array}$ & $\begin{array}{l}\text { Refer- } \\
\text { ents } \\
\text { (N) }\end{array}$ & $\begin{array}{c}\text { Adjusted } \\
0 R^{d} \\
\end{array}$ & $95 \% \mathrm{Cl}$ & $\begin{array}{l}\text { Cases } \\
(\mathrm{N})\end{array}$ & $\begin{array}{l}\text { Refer- } \\
\text { ents } \\
\text { (N) }\end{array}$ & $\begin{array}{l}\text { Adjusted } \\
\mathrm{OR}^{\mathrm{d}}\end{array}$ & $95 \% \mathrm{Cl}$ & $\begin{array}{c}\text { Cases } \\
(\mathrm{N})\end{array}$ & $\begin{array}{l}\text { Refer- } \\
\text { ents } \\
\text { (N) }\end{array}$ & $\begin{array}{l}\text { Adjusted } \\
\mathrm{OR}^{\mathrm{d}}\end{array}$ & $95 \% \mathrm{Cl}$ \\
\hline $\begin{array}{l}\text { Professionals, administrative } \\
\text { clerical and managerial }(1-3)\end{array}$ & 74 & 117 & 1.02 & $0.69-1.50$ & 33 & 57 & 0.84 & $0.49-1.43$ & 25 & 39 & 0.88 & $0.48-1.60$ \\
\hline Sales workers (3) & 64 & 116 & 1.01 & $0.68-1.49$ & 31 & 65 & 0.68 & $0.41-1.12$ & 27 & 48 & 0.71 & $0.41-1.23$ \\
\hline Cooks (531) & 1 & 10 & 0.17 & $0.02-1.43$ & 1 & 1 & 1.20 & $0.07-20.0$ & - & - & . & . \\
\hline Waiters (532) & 5 & 13 & 0.52 & $0.17-1.55$ & 1 & 5 & 0.33 & $0.03-4.19$ & 1 & 4 & 0.45 & $0.04-5.21$ \\
\hline Launders (560) & 2 & 8 & 0.65 & $0.13-3.32$ & 1 & 4 & 1.25 & $0.06-26.9$ & 1 & 4 & 1.25 & $0.06-26.9$ \\
\hline $\begin{array}{l}\text { Other services workers } \\
\text { (other } 5 \text { ) }\end{array}$ & 54 & 95 & 1.19 & $0.79-1.79$ & 19 & 36 & 1.04 & $0.47-2.31$ & 16 & 28 & 1.43 & $0.58-3.50$ \\
\hline Agricultural workers (6) & 100 & 234 & 0.69 & $0.48-1.00$ & 69 & 162 & 0.86 & $0.48-1.52$ & 63 & 140 & 0.89 & $0.49-1.63$ \\
\hline Textile workers (75) & 12 & 25 & 1.03 & $0.48-2.22$ & 6 & 5 & 3.38 & $0.12-95.1$ & 6 & 3 & 6.76 & $0.32-141.6$ \\
\hline Tailors and related workers (79) & 3 & 12 & 0.38 & $0.10-1.44$ & 2 & 9 & 1.50 & $0.12-18.4$ & 2 & 8 & 2.00 & $0.17-24.1$ \\
\hline Shoemakers (801) & 6 & 13 & 0.84 & $0.30-2.39$ & 1 & 5 & 0.14 & $0.01-1.57$ & 1 & 5 & 0.14 & $0.01-1.57$ \\
\hline Wood workers $(73-81)$ & 15 & 21 & 1.22 & $0.59-2.54$ & 10 & 12 & 0.89 & $0.14-5.69$ & 9 & 11 & 0.72 & $0.12-4.33$ \\
\hline Toolmakers (83) & 169 & 324 & 0.88 & $0.62-1.25$ & 120 & 221 & 1.19 & $0.75-1.86$ & 97 & 169 & 1.13 & $0.71-1.79$ \\
\hline Machinery filters (84) & 159 & 303 & 0.87 & $0.62-1.23$ & 109 & 203 & 1.11 & $0.70-1.76$ & 91 & 156 & 1.17 & $0.72-1.88$ \\
\hline Electrical workers (85) & 156 & 295 & 0.90 & $0.64-1.26$ & 104 & 192 & 1.06 & $0.67-1.67$ & 86 & 147 & 1.09 & $0.68-1.75$ \\
\hline Plumbers and welders ( 87 ) & 147 & 283 & 0.89 & $0.63-1.24$ & 98 & 175 & 1.16 & $0.73-1.85$ & 81 & 134 & 1.17 & $0.72-1.92$ \\
\hline Printers (92) & 136 & 275 & 0.80 & $0.57-1.12$ & 91 & 167 & 1.20 & $0.75-1.94$ & 74 & 127 & 1.20 & $0.73-1.99$ \\
\hline Painters (8) & 128 & 259 & 0.77 & $0.56-1.08$ & 82 & 147 & 1.29 & $0.79-2.11$ & 70 & 116 & 1.28 & $0.77-2.15$ \\
\hline Construction workers (95) & 93 & 170 & 0.97 & $0.69-1.37$ & 47 & 76 & 1.14 & $0.62-2.09$ & 39 & 59 & 1.14 & $0.60-2.17$ \\
\hline Dockers (971) & 5 & 6 & 1.25 & $0.36-4.42$ & - & 1 & $\cdot$ & & - & - & $\cdot$ & \\
\hline Drivers (98) & 36 & 61 & 1.00 & $0.62-1.61$ & 27 & 40 & 1.75 & $0.56-5.48$ & 23 & 32 & 1.34 & $0.43-4.15$ \\
\hline $\begin{array}{l}\text { Other production workers } \\
\text { (other } 7,8,9 \text { ) }\end{array}$ & 28 & 41 & 1.37 & $0.79-2.35$ & 17 & 28 & 0.51 & $0.10-2.44$ & 14 & 19 & 0.60 & $0.12-2.91$ \\
\hline
\end{tabular}

Categories with at least 10 subjects employed.

b Code of the International Standard Classification of Occupations (ISCO), revised 2nd edition, in parentheses

- Reference category: never employed.

d Odds ratio adjusted for age, cigarette smoking, cancer in family, migratory history, and socioeconomic status

$\geq 10$ years. Crystalline silica in the form of quartz and crystobolite is carcinogenic to humans (23) and in the pottery industry such exposures occur at high levels (24). Several other potential lung carcinogens are present in pottery and ceramic manufacturing also, for example, talc dust and metals, including antimony, chromium, copper, iron, and titanium (25).

The analysis excluding the proxy interviews detected an expressively increased risk for textile workers exposed for $\geq 10$ years and with $\geq 40$ years of latency. Results of other lung cancer studies for textile workers do not agree; The difference possibly reflects variations in industrial processes and exposure profiles to carcinogens. The textile manufacturing industry entails potential exposure to several chemicals (dyes, solvents, oils, formaldehyde, resins, fumigants, and flame retardants) and organic dust (26).

We interpret the results of the job-exposure matrix as being affected by nondifferential misclassification with respect to the assessment of exposure. The high sensitivity and low specificity of our matrix could be due to data collecting deficiencies with respect to the specific agents examined. The matrix classified about $44 \%$ of all the male cases and referents as ever exposed to arsenic, $66 \%$ to asbestos, $67 \%$ to $\mathrm{PAH}$, and $74 \%$ to dust. These figures probably represent an overestimate of exposure in the male population source of the cases and referents.

Other biases may have affected our study also. For example, 398 incident lung cancer cases in 1 year is only a part of the overall figure, estimated to be 1000 new cases ${ }^{5}$ for the metropolitan region used in this study, and we could not exclude the possibility that selection through hospitals might have introduced some bias.

It has been assumed that the levels of carcinogenic exposure are higher in work settings in developing countries than in developed countries (27), and higher risks of cancer can

5 Data from the Mortality Information Program of the city of São Paulo revealed 1211 deaths from lung cancer (ICD code 162) between 1 July 1990 and 30 June 1991; 842 of the decedents were men. Considering the high death fatality rate after the diagnosis, we can conclude that a minimum of 1000 new cases of lung cancer occurred during the study period in the metropolitan region of São Paulo (including São Paulo county and 36 other municipalities). 
Table 5. Exposure to asbestos, polycyclic aromatic hydrocarbons (PAH), arsenic, dust, nickel and chromium as estimated via a jobexposure matrix and risk of lung cancer among the men. ${ }^{a}(\mathrm{OR}=$ odds ratio, $95 \% \mathrm{Cl}=95 \%$ confidence interval)

\begin{tabular}{|c|c|c|c|c|c|c|c|c|c|c|c|c|}
\hline \multirow[t]{2}{*}{ Exposure } & \multicolumn{4}{|c|}{ Ever $^{b}$} & \multicolumn{4}{|c|}{ Ever with $\geq 10$ years of duration } & \multicolumn{4}{|c|}{$\begin{array}{c}\text { Ever with } \geq 10 \text { years of duration and } \\
\geq 40 \text { years of latency }\end{array}$} \\
\hline & $\begin{array}{l}\text { Cases } \\
\text { (N) }\end{array}$ & $\begin{array}{l}\text { Referents } \\
\text { (N) }\end{array}$ & $O R^{c}$ & $95 \% \mathrm{Cl}$ & $\begin{array}{l}\text { Cases } \\
(\mathrm{N})\end{array}$ & $\begin{array}{l}\text { Referents } \\
\text { (N) }\end{array}$ & $0 \mathrm{R}^{\mathrm{c}}$ & $95 \% \mathrm{Cl}$ & $\begin{array}{l}\text { Cases } \\
(\mathrm{N})\end{array}$ & $\begin{array}{l}\text { Referents } \\
\text { (N) }\end{array}$ & $O R^{c}$ & $95 \% \mathrm{Cl}$ \\
\hline \multicolumn{13}{|l|}{ Any exposure } \\
\hline $\begin{array}{l}\text { Asbestos } \\
\text { PAH } \\
\text { Arsenic } \\
\text { Dust } \\
\text { Nickel } \\
\text { Chromium }\end{array}$ & $\begin{array}{r}158 \\
161 \\
98 \\
184 \\
19 \\
76\end{array}$ & $\begin{array}{r}345 \\
346 \\
234 \\
382 \\
43 \\
169\end{array}$ & $\begin{array}{l}0.80 \\
0.95 \\
0.83 \\
1.02 \\
0.91 \\
0.99\end{array}$ & $\begin{array}{l}0.51-1.24 \\
0.60-1.48 \\
0.57-1.21 \\
0.58-1.81 \\
0.50-1.67 \\
0.68-1.45\end{array}$ & $\begin{array}{r}147 \\
147 \\
84 \\
171 \\
14 \\
60\end{array}$ & $\begin{array}{r}308 \\
311 \\
183 \\
352 \\
22 \\
120\end{array}$ & $\begin{array}{l}1.02 \\
1.08 \\
1.08 \\
1.13 \\
1.31 \\
1.19\end{array}$ & $\begin{array}{l}0.68-1.53 \\
0.72-1.62 \\
0.73-1.58 \\
0.70-1.83 \\
0.62-2.75 \\
0.79-1.78\end{array}$ & $\begin{array}{r}124 \\
125 \\
79 \\
145 \\
10 \\
46\end{array}$ & $\begin{array}{r}238 \\
239 \\
156 \\
271 \\
15 \\
91\end{array}$ & $\begin{array}{l}1.12 \\
1.18 \\
1.16 \\
1.30 \\
1.44 \\
1.16\end{array}$ & $\begin{array}{l}0.75-1.67 \\
0.79-1.76 \\
0.78-1.72 \\
0.83-2.05 \\
0.59-3.50 \\
0.74-1.82\end{array}$ \\
\hline \multicolumn{13}{|l|}{$\begin{array}{l}\text { Possibly high } \\
\text { exposure }\end{array}$} \\
\hline $\begin{array}{l}\text { Asbestos } \\
\text { PAH } \\
\text { Arsenic } \\
\text { Dust } \\
\text { Nickel } \\
\text { Chromium }\end{array}$ & $\begin{array}{r}144 \\
144 \\
98 \\
168 \\
19 \\
76\end{array}$ & $\begin{array}{r}297 \\
304 \\
231 \\
331 \\
43 \\
168\end{array}$ & $\begin{array}{l}1.03 \\
1.07 \\
0.84 \\
1.46 \\
0.91 \\
1.00\end{array}$ & $\begin{array}{l}0.68-1.54 \\
0.71-1.60 \\
0.58-1.23 \\
0.93-2.31 \\
0.50-1.67 \\
0.69-1.46\end{array}$ & $\begin{array}{c}134 \\
132 \\
84 \\
157 \\
14 \\
60\end{array}$ & $\begin{array}{r}269 \\
278 \\
181 \\
312 \\
22 \\
119\end{array}$ & $\begin{array}{l}1.13 \\
1.13 \\
1.09 \\
1.34 \\
1.31 \\
1.20\end{array}$ & $\begin{array}{l}0.77-1.67 \\
0.76-1.66 \\
0.74-1.61 \\
0.88-2.06 \\
0.62-2.75 \\
0.80-1.79\end{array}$ & $\begin{array}{r}114 \\
113 \\
79 \\
136 \\
10 \\
46\end{array}$ & $\begin{array}{r}120 \\
214 \\
155 \\
244 \\
15 \\
90\end{array}$ & $\begin{array}{l}1.23 \\
1.23 \\
1.16 \\
1.48 \\
1.44 \\
1.17\end{array}$ & $\begin{array}{l}0.83-1.82 \\
0.83-1.82 \\
0.78-1.73 \\
0.97-2.26 \\
0.59-3.50 \\
0.75-1.84\end{array}$ \\
\hline \multicolumn{13}{|l|}{$\begin{array}{l}\text { Definite high } \\
\text { exposure }\end{array}$} \\
\hline $\begin{array}{l}\text { Asbestos } \\
\text { PAH } \\
\text { Arsenic } \\
\text { Dust } \\
\text { Nickel } \\
\text { Chromium }\end{array}$ & $\begin{array}{c}13 \\
48 \\
1 \\
140 \\
4 \\
4\end{array}$ & $\begin{array}{r}28 \\
98 \\
1 \\
292 \\
9 \\
12\end{array}$ & $\begin{array}{l}0.83 \\
1.02 \\
.11 \\
1.11 \\
1.13 \\
0.98\end{array}$ & $\begin{array}{c}0.40-1.73 \\
0.66-1.56 \\
- \\
0.74-1.66 \\
0.32-3.99 \\
0.29-3.32\end{array}$ & $\begin{array}{r}12 \\
45 \\
5 \\
132 \\
3 \\
3\end{array}$ & $\begin{array}{r}26 \\
95 \\
\cdot \\
278 \\
6 \\
9\end{array}$ & $\begin{array}{l}0.85 \\
0.99 \\
. \\
1.09 \\
1.43 \\
1.14\end{array}$ & $\begin{array}{c}0.40-1.79 \\
0.64-1.52 \\
- \\
0.73-1.62 \\
0.32-6.36 \\
0.28-4.68\end{array}$ & $\begin{array}{r}11 \\
34 \\
6 \\
118 \\
1 \\
1\end{array}$ & $\begin{array}{r}22 \\
66 \\
\cdot \\
222 \\
3 \\
5\end{array}$ & $\begin{array}{l}0.87 \\
1.02 \\
. \\
1.26 \\
1.37 \\
0.99\end{array}$ & $\begin{array}{r}0.39-1.91 \\
0.63-1.66 \\
- \\
0.84-1.89 \\
0.13-14.0 \\
0.11-9.09\end{array}$ \\
\hline
\end{tabular}

a Excluding proxy interviews.

b Reference category: never exposed.

c Odds ratio adjusted by age, cigarette smoking, cancer in family and migration history, and socioeconomic status.

Table 6. Smoking effect of estimated relative risk of the men. ${ }^{a}(\mathrm{OR}=$ odds ratio, $95 \% \mathrm{Cl}=95 \%$ confidence interval, $\mathrm{PAH}=$ polycyclic aromatic hydrocarbons)

\begin{tabular}{|c|c|c|c|c|c|c|}
\hline \multirow[t]{2}{*}{ Exposureb } & \multirow[t]{2}{*}{ Cases } & \multirow[t]{2}{*}{ Referents } & \multicolumn{2}{|c|}{ No smoking adjustment } & \multicolumn{2}{|c|}{ With smoking adjustment } \\
\hline & & & $O R^{\circ}$ & $95 \% \mathrm{Cl}$ & ORc & $95 \% \mathrm{Cl}$ \\
\hline Asbestos & 158 & 345 & 0.73 & $0.49-1.09$ & 0.80 & $0.51-1.24$ \\
\hline $\mathrm{PAH}$ & 161 & 346 & 0.84 & $0.56-1.27$ & 0.95 & $0.60-1.48$ \\
\hline Arsenic & 98 & 234 & 0.71 & $0.50-1.00$ & 0.83 & $0.57-1.21$ \\
\hline Dust & 184 & 382 & 0.85 & $0.51-1.44$ & 1.02 & $0.58-1.81$ \\
\hline Nickel & 19 & 43 & 0.93 & $0.52-1.65$ & 0.91 & $0.50-1.67$ \\
\hline Chromium & 76 & 169 & 0.99 & $0.68-1.45$ & 0.89 & $0.63-1.27$ \\
\hline Pottery industry (ISIC 361) & 14 & 13 & 2.38 & $1.10-5.16$ & 2.54 & $1.09-5.88$ \\
\hline Machinery industry (ISIC $382-4$ ) & 40 & 58 & 1.51 & $0.96-2.37$ & 1.61 & $0.99-2.61$ \\
\hline Textile workers (ISCO 75) & 9 & 23 & 0.88 & $0.40-1.96$ & 1.00 & $0.43-2.34$ \\
\hline
\end{tabular}

a Excluding proxy interviews.

b Ever-never exposed (reference category: never exposed); code of the International Standard Industrial Classification of All Economic Activities (ISIC) or the International Standard Classification of Occupations (ISCO) in parentheses.

- Odds ratio adjusted by age, cigarette smoking, cancer in family, migration history, and socioeconomic status.

be observed in industries and occupations of developing countries. We were unable to detect such differences clearly. Exposure to carcinogens may be higher in work settings of developing countries, but the latency may not yet be long enough to reveal its effect in epidemiologic studies. There are no time-pattern series of well-known cancer-related industries in São Paulo, and there is no indirect approach that can be used to throw more light on this problem. However, the very high risks of lung cancer among the textile and pottery workers exposed $\geq 10$ years and with $\geq 40$ years of latency are a strong expression of the exposure to carcinogens in these industries, the oldest in Brazil.

\section{Acknowledgments}

This research was supported by funds of the São Paulo Health Metropolitan Program/World Bank and developed in the Health Institute of São Paulo State. This report was prepared during the tenure of a fellowship from the Brazilian 
National Council for Scientific and Technological Development $(\mathrm{CNPq})$ to Victor Wünsch-Filho in 1995-1996 at the International Agency for Research on Cancer (IARC).

The study was made possible by the support of many people. We are pleased to acknowledge the advice and technical assistance of Drs Cecilia Magaldi and Neusa Nakao. We would like to thank Didier Colin for his assistance with the statistical analysis, Dr Franco Berrino for his comments on our proposal of a job-exposure matrix, and also Drs Eduardo Algranti, Ubiratan de Paula Santos, Myriam Debert-Ribeiro and Nubia Muñoz for their helpful comments on the project.

We are grateful to the medical staffs of the hospitals where the study was conducted, particularly the following clinicians for their full cooperation: Drs Antonio P Mirra, Hospital ACCamargo; José R Pereira, Instituto AV de Carvalho; João V Barbas Filho and Tereza Takagaki, Hospital das Clínicas/USP; Hakaru Tadakaru and Sérgio Jamnik, Hospital São Paulo/UNIFESP; Salvador Mercútio, Hospital Heliópolis; Jorge Afiune, Instituto Clemente Ferreira; Nelson Morrone, Luiz AM Fonseca and Carlos AC Pereira, Hospital Ipiranga and Hospital Servidor Municipal; Ilka L Santoro, Hospital do Mandaqui; Mozart T de Lima, Hospital do Servidor Estadual; Jorge Nakateni, Hospital Sta Marcelina; Roberto Saad Jr and Jorge Ethel Filho, Santa Casa de São Paulo.

\section{References}

1. Ministerio da Saúde, Secretaria Nacional de Ações Básicas de Saúde. Subsistema de Informações sobre Mortalidade [Mortality information system]. Brasil: Estatística de Mortalidade [Mortality Statistics], 1988. Centro de Documentação do Ministério da Saúde, Brasilia 1993.

2. Coleman MP, Esteve J, Damiecki P, Arslan A, Renard, H. Trends in cancer incidence and mortality. Lyon: International Agency for Research on Cancer (IARC), 1993. IARC scientific publications, no 121.

3. Fonseca LAM. A evolução das doenças neoplásicas [Neoplasms evolution]. In: Monteiro CA, editor. Velhos e novos males da saúde no Brasil: a evolução do país e de suas doenças [New and old health problems in Brazil: the country evolution and their diseases]. São Paulo: Hucitec, 1995:268-78.

4. Ministério da Saúde. Câncer no Brasil, dados dos registros de base populacional [Cancer in Brazil, data from the Populational Cancer Registries]. Rio de Janeiro: Ministério da Saúde, Instituto Nacional do Câncer (INCA), 1991.

5. Ministério da Saúde. Câncer no Brasil, dados dos registros de base hospitalar [Cancer in Brazil, data from the Hospitalar Cancer Registries]. Rio de Janeiro: Ministério da Saúde, Instituto Nacional do Câncer (INCA), 1993.

6. Mirra AP, Franco EL, editors. Cancer incidence in São Paulo County, Brazil: 1969, 1973, 1978. São Paulo: São Paulo Cancer Registry and Ludwig Institute for Cancer Research, 1985.

7. International Agency for Research on Cancer (IARC). IARC Tobacco smoking. Lyon: IARC, 1986. IARC monographs on the evaluation of carcinogenic risks to humans, vol 38.

8. Suzuki I, Hamada GS, Zamboni MM, Cordeiro PB, Watanabe S, Tsugane S. Risk factors for lung cancer in Rio de Janeiro, Brazil: a case-control study. Lung Cancer 1994;11:179-90.

9. Boffetta P, Saracci R. Occupational factors of lung cancer. In: Hirsch
A, Goldberg M, Martin JP, Masse R. editors. Prevention of respiratory diseases. New York (NY): Marcel Dekker Inc, 1993:37-63.

10. Vineis $P$, Simonato L. Proportion of lung and bladder cancer in males resulting from occupation: a systematic approach. Arch Environ Health 1991;46:6-15.

11. International Agency for Research on Cancer (IARC). Overall evaluations of carcinogenicity: an updating of IARC monographs volumes 1 to 42. Lyon: IARC, 1987. IARC monographs on the evaluation of carcinogenic risks to humans, suppl 7.

12. Levin LI, Zheng W, Blot WJ, Gao Y-T, Fraumeni Jr, JF. Occupation and lung cancer in Shangai: a case-control study. $\mathrm{Br} J \mathrm{Ind} \mathrm{Med}$ 1988;45:450—8.

13. Notani PN, Priyabala S, Kasturi J, Balakrishnan V. Occupation and cancers of lung and bladder: a case-control study in Bombay. Int J Epidemiol 1993;22:185-91.

14. Wang Q-S, Boffetta P, Kogevinas M, Parkin DM. Cancer incidence by occupation and industry in Tianjin, China, 1981-1987. Lyon: International Agency for Research on Cancer (IARC), 1994. IARC technical report, no 22.

15. Fundação Instituto Brasileiro de Geografia e Estatística (IBGE). Anuário estatístico do Brasil: 1992 [Brazilian annual statistics: 1992]. Rio de Janeiro: Fundação IBGE, 1993.

16. Fundação Sistema Estadual de Análises de Dados (SEADE). Anuário Estatístico do Estado de São Paulo, 1990 [São Paulo State Annual Statistics, 1990]. São Paulo: Fundação SEADE, 1991.

17. World Health Organization (WHO). International classification of diseases: manual of the international statistical classification of diseases, injury and causes of death. 9th rev. Geneva: WHO, 1975.

18. United Nations (UN). International standard industrial classification of all economic activities. New York (NY): UN, 1971.

19. International Labour Office (ILO). International standard classification of occupations. 2nd ed. Geneva: ILO, 1968.

20. Breslow NE, Day NE. Statistical methods in cancer research; vol 1 (The analysis of case-control studies). Lyon: International Agency for Research on Cancer (IARC), 1980. IARC scientific publications, no 32 .

21. Hosmer DM, Lameshow S. Applied logistic regression. New York (NY): John Willey \& Sons, 1989.

22. Restrepo HE, Correa P, Haenszel W, Brinton LA, Franco A. A casecontrol study of tobacco-related cancers in Colombia. Bull Pan Am Health Organ 1989;23:405-13.

23. International Agency for Research on Cancer (IARC). Silica, some silicats, coal dust and para-aramid fibrils. Lyon: IARC, 1997. IARC monographs on the evaluation of carcinogenic risks to humans, vol 68.

24. McDonald JC, Cherry N, McNamee R, Burgess G, Turner S. Preliminary analysis of proportional mortality in a cohort of British pottery workers exposed to crystalline silica. Scand J Work Environ Health 1995;21 suppl 2:63-5.

25. Thomas TL. Lung cancer mortality among pottery workers in the United States. In: Simonato L, Fletcher AC, Saracci R, Thomas TL, editors. Occupational exposure to silica and cancer risk. Lyon: International Agency for Research on Cancer (IARC), 1990. IARC scientific publications, no 97.

26. International Agency for Research on Cancer (IARC). Some flame retardants and textile chemicals, and exposure in the textile manufacturing industry. Lyon: IARC, 1990. IARC monographs on the evaluation of carcinogenic risks to humans, vol 48.

27. Pearce N, Matos E. Introduction. In: Pearce N, Matos E, Vainio H, Boffetta P, Kogevinas M, editors. Occupational cancer in developing countries. Lyon: IARC, 1994. IARC scientific publications, no 129.

Received for publication: 10 June 1997 